\title{
ANALISI NILAI TAMBAH KACANG SANGRAI UD. MERPATI DI DESA TOMBASIAN ATAS KECAMATAN KAWANGKOAN BARAT
}

\author{
Filia Christi Batas \\ Leonardus Ricky Rengkung \\ Juliana Ruth Mandei
}

Naskah diterima melalui email jurnal ilmiah agrisosioekonomi@unsrat.ac.id

: Rabu, 29 Januari 2020

Disetujui diterbitkan

: Jumat, 29 Mei 2020

\begin{abstract}
The purpose of this research is to analyze the value added of raw peanuts to roasted peanuts. This research was conducted at UD. "Merpati" at Tombasian Atas Village, West Kawangkoan Sub-district. Primary data collection is done through direct interviews, with the help of a list of questions, to the owner who is a entrepreneur and manager of the roasted peanuts processing industry and to employees. Added value is the difference in the value of output with the value of the main raw materials and the contribution of other inputs (IDR/ $\mathrm{kg})$. The results showed that the added value obtained of $1 \mathrm{~kg}$ of raw peanuts at a price of IDR 4,000 processed into roasted peanuts at a price of IDR. 22,000, - Add value for $1 \mathrm{~kg}$ of roasted peanuts that have been packaged, that is IDR. 45,000,-. ${ }^{*}{ }^{2}{ }^{*}$
\end{abstract}

Keywords: added value, roasted peanuts, Village of Tombasian Village

\begin{abstract}
ABSTRAK
Penelitian ini bertujuan untuk menganalisis nilai tambah kacang tanah mentah menjadi kacang sangrai. Penelitian ini dilaksanakan di UD. "Merpati" di Desa Tombasian Atas Kecamatan Kawangkoan Barat. Pengumpulan data primer dilakukan melalui wawancara langsung, dengan bantuan daftar pertanyaan, pada pemilik sekaligus pengusaha dan pengelola industri pengolahan kacang sangrai dan karyawan. Nilai tambah merupakan selisih nilai output dengan nilai bahan baku utama dan sumbangan input lain $(\mathrm{Rp} / \mathrm{kg})$. Hasil penelitian menunjukan bahwa Nilai Tambah yang diperoleh untuk $1 \mathrm{~kg}$ kacang mentah dengan harga Rp. 4.000 menjadi kacang sangrai dengan harga sebesar Rp. 22.000,- Nilai Tambah untuk $1 \mathrm{~kg}$ kacang sangrai yang sudah dikemas yaitu Rp. $45.000,-{ }^{*}{ }^{*}$ prm*
\end{abstract}

Kata kunci: nilai tambah, kacang sangrai, Desa Tombasian Atas

Agrisosioekonomi: 


\section{PENDAHULUAN}

\section{Latar Belakang}

Pertanian merupakan salah satu sektor yang berperan dalam perekonomian di Indonesia termasuk negara agraris yang kaya akan sumber daya alam. Pertumbuhan sektor pertanian di Indonesia tergolong dalam sasaran pertumbuhan yang cukup tinggi (Tambunan, 2003). Sektor pertanian merupakan sektor yang mendapatkan perhatian besar dari pemerintah disebabkan peranannya yang penting dalam rangka prembangunan ekonomi jangka panjang maupun dalam rangka pemulihan ekonomi bangsa.

Sjarkowi dan Sufri (2004) menyatakan setiap usaha yang berkaitan dengan kegiatan produksi pertanian, yang meliputi pengusahaan input pertanian dan atau pengusahaan produksi itu sendiri ataupun juga pengusahaan hasil pertanian. Dengan kata lain agribisnis adalah cara pandang ekonomi bagi penyedia pangan. Secara garis besar, kegiatan pertanian dalam sistem agribisnis terbagi menjadi dua yaitu kegiatan on farm (hulu) dan off farm (hilir). Kegiatan on farm merupakan subsistem agroindustri hulu yang berkaitan dengan sarana produksi pertanian dan budidaya pertanian. Kegiatan off farm merupakan subsistem agroindustri hilir yang berhubungan dengan kegiatan pengelolahan dan pemasaran hasil pertanian.

Agroindustri merupakan salah satu subsistem agribisnis yang strategis, yaitu suatu bentuk keterpaduan antara sektor industri dan pertanian. Agroindustri diharapkan sebagai langkah awal pembangunan sektor industri terutama bagi negara yang di dominasi sektor pertanian, menciptakan kondisi yang mendukung industri maju dengan pertanian tangguh, juga memberikan efek ganda melalui penciptaan lapangan kerja, perbaikan distribusi pendapatan, nilai tambah serta pembangunan pertanian yang berbasis agribisnis (Saragih, 2004). Kegiatan agroindustri atau industri hasil pertanian merupakan bagian integral dari sektor pertanian yang memberikan kontribusi penting pada proses industrialisasi di wilayah pedesaan. Pengaruh agroindustri tidak hanya mentransformasi produk primer ke produk olahan tetapi peralihan budaya kerja dari agraris tradisional yang menciptakan nilai tambah rendah menjadi budaya kerja industrial modern yang menciptakan nilai tambah tinggi (Suryana, 2004). Hasil-hasil produksi pertanian di Indonesia antara lain, kelapa yang bisa diolah menjadi gula kelapa, Jagung diolah menjadi kripik jagung, singkong diolah menjadi tepung, pisang diolah menjadi kripik pisang, pala diolah menjadi manisan pala, tebu diolah menjadi gula tebu dan kacang tanah diolah menjadi kacang sangrai.

Kacang tanah mempunyai nilai ekonomi yang tinggi karena kandungan gizinya terutama protein dan lemak yang tinggi. Kacang tanah adalah bahan makanan paling banyak digunakan oleh bahan baku industri yang dapat diolah dalam bentuk lain seperti kacang atom, rempeyek, manisan, kacang sanghai dan kacang sangrai. Kacang tanah mentah tidak bisa dikonsumsi secara berlebihan karena dapat menyebabkan penyakit, dan tidak dapat disimpan dalam waktu yang lama karena akan mengalami kerusakan atau pembusukan. Untuk menghindari hal tersebut maka diperlukan penanganan dan pengolahan yaitu dengan cara diolah menjadi kacang sangrai, kacang sangrai adalah kacang tanah yang diproduksi tanpa mengubah bentuk dan rasanya. Tingginya nilai tambah yang diperoleh pelaku usaha agroindustri dapat memicu persaingan menjadi semakin meningkat baik dalam memperoleh bahan baku maupun pemasaran produk olahannya. Salah-satu tempat yang memproduksi kacang sangrai adalah Kawangkoan.

Kawangkoan terletak di Kabupaten Minahasa yang memproduksi kacang sangrai. Ada beberapa UD Sekaligus nama merk dagang di Kawangkoan yang memproduksi kacang mentah menjadi kacang sangrai antara lain Tarsius, Ribka, Mona, Grafinka, Friska, Virgin dan Merpati.

UD. Merpati adalah salah-satu dari sekian banyak usaha kacang sangrai di kawangkoan yang penjualannya sudah ada di toko-toko skala kecil, menengah, besar, dibandingkan dengan usaha kacang sangrai yang 
lain penjualannya masih di beberapa tempat. Kacang sangrai "Merpati" adalah salah satu usaha yang berada di Desa Tombasian atas kecamatan Kawangkoan barat yang bergerak di bidang industri kacang sangrai. Usaha ini telah bergerak sejak tahun 1996 dan sampai saat ini produk yang dihasilkan hanya kacang sangrai dan sangat laris di Pasaran.

Nilai tambah adalah pertambahan nilai suatu komoditas karena mengalami proses pengolahan, pengangkutan ataupun penyimpanan dalam suatu produksi. Dalam proses pengolahan nilai tambah dapat didefinisikan sebagai selisih antara nilai produk dengan nilai biaya bahan baku dan biaya input lainnya tidak termasuk tenaga. Tingginya nilai tambah yang diperoleh pelaku usaha agroindustri dapat memicu persaingan menjadi menjadi semakin meningkat baik dalam memperoleh bahan baku maupun pemasaran produk olahannya. Nilai tambah kacang sangrai UD. Merpati diukur dengan menggunakan perhitungan Hayami, Analisis nilai tambah hayami merupakan metode yang memperkirakan perubahan nilai bahan baku setelah mendapat perlakuan, nilai tambah yang terjadi dalam proses pengolahan merupakan selisih dari nilai produk dengan biaya bahan baku dan input lainnya. Dengan adanya industri yang mengubah bentuk primer menjadi produk baru yang lebih tinggi nilai ekonomisnya setelah melalui proses pengolahan, maka akan dapat memberikan nilai tambah karena dikeluarkannya biaya-biaya sehingga terbentuk harga baru yang lebih tinggi dan keuntungannya lebih besar bila dibandingkan tanpa melalui proses pengolahan.

\section{Rumusan Masalah}

Rumusan masalah dalam penelitian ini untuk menganalisis nilai tambah dari usaha pengolahan kacang sangrai pada UD. Merpati di Desa Tombasian Atas Kecamatan Kawangkoan Barat Kabupaten Minahasa.

\section{Tujuan Penelitian}

Untuk menganalisis nilai tambah dari pengolahan kacang sangrai pada UD. Merpati di Desa Tombasian Atas Kecamatan Kawangkoan Barat Kabupaten Minahasa.

\section{Manfaat Penelitian}

1. Bagi peneliti dapat melatih cara berpikir serta menganalisis data, dan penelitian ini merupakan salah satu syarat untuk memperoleh gelar sarjana di Fakultas Pertanian Universitas Sam Ratulangi Manado.

2. Bagi pemerintah penelitian ini diharapkan dapat memberikan informasi bagi pemerintah dan masyarakat berupa datadata terkait pemanfaatan, keuntungan serta nilai tambah dari produk dari kacang tanah.

3. Bagi peneliti lain, dapat dijadikan referensi kajian dalam bidang penelitian.

\section{METODE PENELITIAN}

\section{Waktu dan Tempat Penelitian}

Penelitian ini telah dilakukan pada UD. Merpati yang berlokasi Desa Tombasian Atas, Kecamatan Kawangkoan Barat, Kabupaten Minahasa dan waktu penelitian dilaksanakan pada bulan September sampai November 2019.

\section{Metode Pengumpulan Data}

Data dalam penelitian ini menggunakan data Primer yang dikumpulkan dan diperoleh dari pengusaha kacang sangrai UD. Merpati dengan menggunakan daftar pertanyaan.

\section{Konsep Pengukuran Variabel}

Pengukuran Variabel Dalam penelitian adalah:

1. Output adalah jumlah yang dihasilkan dalam satu kali produksi $(\mathrm{Kg})$.

2. Bahan baku meliputi bahan mentah yang digunakan dalam satu kali produksi $(\mathrm{Kg})$

3. Tenaga kerja adalah banyaknya hari orang kerja (HOK) yang terlibat langsung dalam satu kali proses produksi (HOK/Produksi).

4. Faktor konversi adalah banyaknya output yang dapat dihasilkan dalam satu satuan input, yaitu banyaknya produk yang dihasilkan dari satu kilogram bahan baku (Kg output/kg bahan baku).

5. Koefisien tenaga kerja adalah banyaknya tenaga kerja langsung yang diperlukan untuk mengolah satu kilogram satuan input (HOK/kg proses produksi). 
6. Harga output adalah harga jual produk per satu kilogram $(\mathrm{Rp} / \mathrm{kg})$.

7. Upah tenaga kerja adalah upah rata-rata yang diterima tenaga kerja langsung untuk mengolah produk ( $\mathrm{Rp} / \mathrm{kg}$ proses produksi).

8. Harga bahan baku adalah harga beli bahan baku perkilogram ( $\mathrm{Rp} / \mathrm{kg})$.

9. Sumbangan input lain adalah biaya pemakaian input lain perkilogram produk (Rp/kg output).

10. Nilai output menunjukkan nilai yang dihasilkan dari satu kilogram bahan baku ( $\mathrm{Rp} / \mathrm{kg}$ ).

11. Nilai tambah merupakan selisih nilai output dengan nilai bahan baku utama dan sumbangan input lain $(\mathrm{Rp} / \mathrm{kg})$.

12. Rasio nilai tambah menunjukkan persentase nilai tambah dari nilai produk $(\%)$.

13. Marjin adalah selisih antara nilai output dengan bahan baku atau besarnya kontribusi pemilik faktor-faktor produksi selain bahan baku yang digunakan dalam proses produksi ( $\mathrm{Rp} / \mathrm{kg})$.

14. Pendapatan tenaga kerja adalah hasil kali antara koefisien tenaga kerja dan upah tenaga kerja langsung $(\mathrm{Rp} / \mathrm{kg})$.

15. Bagian tenaga kerja menunjukkan persentase pendapatan tenaga kerja dari nilai tambah $(\%)$.

16. Keuntungan adalah nilai tambah dikurangi pendapatan tenaga kerja $(\mathrm{Rp} / \mathrm{kg})$.

\section{HASIL DAN PEMBAHASAN}

\section{Gambaran Umum Daerah Penelitian}

Kawangkoan Barat adalah salah satu kecamatan di Kabupaten Minahasa Provinsi Sulawesi Utara. Ibu kota Kawangkoan Barat berkedudukan di Desa Kayuuwi satu. Secara geografis kecamatan kawangkoan barat terletak pada $11^{\circ}$ - $128^{\circ} \mathrm{LU}$ dan $124^{\circ}$ - $48^{\circ} \mathrm{BT}$ dengan ketinggian permukaan laut \pm 700 Meter. Curah hujan $\pm 3.100 \mathrm{~mm}$ pertahun, topografi tanah sebagian besar bergelombang dengan batas-batas wilayah sebagai berikut:

$\begin{array}{ll}\text { Utara } & \text { : Berbatasan dengan Kecamatan } \\ & \text { Kawangkoan Utara. } \\ \text { Selatan } & \text { : Berbatasan dengan Kecamatan } \\ & \text { Tompaso Barat dan unung } \\ & \text { Tonderukan. } \\ \text { Timur } & \text { : Berbatasan dengan Kecamatan } \\ & \text { Kawangkoan dan Tompaso } \\ & \text { Barat. } \\ \text { Barat } & \text { : Berbatasan dengan Kecamatan } \\ & \text { Tareran kabupaten Minahasa } \\ & \text { Selatan }\end{array}$

Kecamatan Kawangkoan Barat merupakan bagian integral dari Kabupaten Minahasa yang memiliki luas $\pm 19,27 \mathrm{~km}^{2}$ yang terbagi dalam 10 wilayah Desa salah satu diantaranya adalah desa Tombasian Atas.

\section{Profil Usaha Kacang Sangrai "Merpati"}

UD. Merpati merupakan industri kacang sangrai yang pertama kali ada di Kecamatan Kawangkoan dan Kawangkoan Barat, telah didirikan sejak tahun 1996. Pemilik usaha industri kacang sangrai merpati adalah Bapak Sampel Frans Kapero, tempat produksi dilakukan di Desa Tombasian Atas Kecamatan Kawangkoan Barat. Jenis kacang tanah yang digunakan dalam industri usaha kacang sangrai adalah kacang batik, kacang belimbing, dan kacang merah super, UD. Merpati lebih sering menggunakan bahan baku kacang batik karena kacang batik lebih berkualitas dan banyak peminat dibandingkan dengan jenis kacang lainnya sehingga peneliti hanya meneliti kacang sangrai jenis batik.

UD. Merpati memproduksi kacang sangrai setiap 5 kali dalam 1 minggu, dengan sekali produksi rata-rata $500 \mathrm{~kg}$ perhari dan menggunakan tenaga kerja sebanyak 11 orang, antara lain 2 orang di bagian penjemuran kacang mentah, 2 orang dibagian pengsangraian, 5 orang dibagian pengepakan, dan 2 orang dibagian pemasaran. UD. Merpati telah membentuk badan usaha sendiri yang diberi nama koperasi serba usaha "Sejati". Kelompok tani sejati sudah berbadan hukum. Kacang tanah yang digunakan oleh UD. Merpati $75 \%$ berasal dari kelompok tani "Sejati", 25\% dari luar kelompok tani. Kacang sangrai merpati sudah 
dipasarkan di beberapa tempat seperti supermarket dan minimarket dan telah memiliki pelanggan tetap seperti Multimart, toko oleh-oleh oma Yuli, toko Maengket Souvenir Manado dan warung-warung kecil di Kawangkoan, setiap 1 atau 2 minggunya UD. Merpati mendistrisibusikan 1.000 pack untuk Multimart, 500 pack untuk toko Oleh-oleh oma Yuli, 200 pack untuk toko maengket souvenir manado dan warung-warung kecil di Kawangkoan 1000 pack per minggu dengan berbagai kemasan. Harga kacang sangrai ukuran 1000g di jual dengan harga Rp.45.000. Tempat produksi kacang sangrai UD. Merpati masih tergolong sederhana akan tetapi permintaan pasar dari produk kacang sangrai UD. Merpati tergolong cukup tinggi.

\section{Biaya Input Lain}

Bahan baku yang digunakan dalam proses pembuatan kacang sangrai UD. Merpati adalah kacang tanah jenis batik. Bahan penolong yang digunakan dalam proses pembuatan kacang sangrai adalah kayu api, pasir, plastik, sablon label. Berikut biaya bahan baku dan bahan penolong kacang tanah dalam satu kali proses produksi dapat dilihat pada Tabel berikut:

\begin{tabular}{lccr} 
Tabel 1. Biaya Input Lain & & \\
\hline Uraian & $\begin{array}{c}\text { Satuan } \\
(\mathbf{K g})\end{array}$ & $\begin{array}{c}\text { Harga satuan } \\
(\mathbf{K g})\end{array}$ & $\begin{array}{c}\text { Total } \\
(\mathbf{R p})\end{array}$ \\
\hline Kayu Api & 500 & 300 & $\mathbf{1 5 0 . 0 0 0}$ \\
Pasir & 100 & 300 & $\mathbf{3 0 . 0 0 0}$ \\
Plastik & 1 & 30.000 & $\mathbf{3 0 . 0 0 0}$ \\
Sablon label & 1 & 30.000 & $\mathbf{3 0 . 0 0 0}$ \\
\hline Total biaya & & & $\mathbf{2 4 0 . 0 0 0}$ \\
\hline Sumber: Diolah dari Data Primer, 2019
\end{tabular}

Jadi, $1 \mathrm{~kg}$ pasir sebesar Rp. 300, 1pcs plastik sebesar Rp. 100 didapat dari harga $1 \mathrm{~kg}$ plastik Rp. 30.000 dibagi dengan $300 \mathrm{~kg}$ kacang sangrai, 1 pcs sablon label sebesar Rp. 100 didapat dari harga $1 \mathrm{~kg}$ sablon label $\mathrm{Rp}$. 30.000 dibagi dengan $300 \mathrm{~kg}$ kacang sangrai.

\section{Proses Pengolahan Kacang Sangrai}

UD. Merpati memproduksi kacang sangrai 5 kali dalam seminggu, dalam 1 kali proses produksi bahan baku yang digunakan adalah $500 \mathrm{~kg}$ kacang tanah. Jenis kacang digunakan untuk disangrai adalah kacang batik.
Dalam melakukan proses produksi pengolahan kacang tanah mentah menjadi kacang sangrai merpati adalah sebagai berikut:

a). Penjemuran

Kacang tanah mentah dilakukan penjemuran terlebih dahulu agar kacang menjadi kering dan mudah untuk disangrai. Proses penjemuran kacang tanah dilakukan oleh 2 orang.

b). Pengsangraian

Kacang tanah mentah yang sudah melewati penjemuran atau kering dilakukan pengsangraian menggunakan wajan dengan diameter sekitar 1.5meter selama kurang lebih satu jam. Proses pembuatan kacang sangrai harus di aduk-aduk dan tidak boleh berhenti karena dapat menyebabkan kacang menjadi hangus. Bahan yang digunakan dalam mengsangrai adalah pasir. Fungsi dari pasir adalah menghilangkan kotor yang menempel pada kulit kacang. kacang mentah $500 \mathrm{~kg}$ menjadi 300kg setelah disangrai. Proses pengsangraian dilakukan oleh 2 orang.

c). Penapisan

Kacang tanah yang sudah disangrai di dinginkan terlebih dahulu kemudian di tapis menggunakan alat tradisional. Fungsi penapisan adalah memisahkan kacang dari sisa-sisa pasir dan serabut-serabut halus yang menempel pada kacang.

d). Penyortiran

Kacang sangrai yang telah ditapis dilakukan penyortiran untuk memisahkan kualitas kacang yang bagus.

e). Pengemasan

Kacang sangrai yang telah melewati penyortiran akan dikemas dengan berbaga kemasan seperti 250g, 500g, dan 1000g. Proses penapisan sampai pengemesan kacang sangrai dilakukan oleh 5 orang.

\section{Penggunaan dan Biaya Tenaga Kerja}

Tenaga kerja merupakan salah satu faktor penting dalam sebuah proses produksi. Tenaga kerja dalam industri pembuatan kacang sangrai di daerah penelitian diperlukan untuk mengerjakan berbagai kegiatan produksi seperti penjemuran, pengsangraian, pengemasan, pemasaran. 
Biaya tenaga kerja adalah biaya yang dikeluarkan selama proses produksi mulai dari kacang tanah mentah hingga menjadi kacang sangrai. Secara rinci, penggunaan tenaga kerja pada pengolahan kacang mentah menjadi kacang sangrai di daerah penelitian dapat dilihat pada Tabel berikut.

Tabel 2. Biaya Tenaga Kerja

\begin{tabular}{lccc}
\hline Uraian & $\begin{array}{c}\text { Tenaga } \\
\text { Kerja } \\
\text { (Orang) }\end{array}$ & $\begin{array}{c}\text { Biaya/Orang } \\
(\mathbf{R p )}\end{array}$ & $\begin{array}{c}\text { Jumlah } \\
(\mathbf{R p )})\end{array}$ \\
\hline Penjemuran & 2 & 70.000 & 140.000 \\
Pengsangraian & 2 & 175.000 & 350.000 \\
Pengemasan & 5 & 60.000 & 300.000 \\
Pemasaran & 2 & 100.000 & 200.000 \\
\hline Total & & & $\mathbf{9 9 0 . 0 0 0}$ \\
\hline
\end{tabular}

Sumber: Diolah dari Data Primer, 2019

\section{Penggunaan Waktu Tenaga Kerja}

Jam kerja adalah waktu untuk melakukan pekerjaan dan dapat dilakukan pagi hari dan/ atau malam hari.

Total waktu yang digunakan untuk memproduksi kacang sangrai UD. Merpati dapat dijelaskan penggunaan waktu tenaga Kerja sebagai berikut:

1. Pengsangraian $500 \mathrm{~kg}$ membutuhkan waktu 225 menit atau 45 menit untuk 50 $\mathrm{kg}$ kacang mentah dilakukan oleh 2 tenaga kerja dalam 2 wajan.

2. Penapisan $300 \mathrm{~kg}$ kacang sangria membutuhkan waktu 300 menit atau 1 menit untuk $1 \mathrm{~kg}$ kacang sangrai dan dilakukan oleh 5 tenaga kerja jadi masing-masing tenaga kerja membutuhkan waktu 60 menit.

3. Penyortiran $300 \mathrm{~kg}$ kacang sangrai membutuhkan waktu 600 menit atau 2 menit untuk $1 \mathrm{~kg}$ kacang sangrai dan dilakukan oleh 5 tenaga kerja, jadi masing-masing tenaga kerja membutuhkan waktu 120 menit.

4. Pengemasan $300 \mathrm{~kg}$ membutuhkan waktu 300 menit atau 1 menit untuk $1 \mathrm{~kg}$ kacang sangrai dan dilakukan oleh 5 tenaga kerja, jadi masing-masing tenaga kerja membutkan waktu 60 menit.

\section{Perhitungan Nilai Tambah}

Nilai tambah (value added) adalah pertambahan nilai suatu komoditas karena mengalami proses pengolahan, pengangkutan ataupun penyimpanan dalam suatu produksi. nilai suatu komoditi karena adanya input fungsional yang diberikan pada komoditi yang bersangkutan.

Hayami et al, 1987 adalah metode yang menjelaskan nilai tambah dan analisis pemasaran dengan analisis kualitatif dan kuantitatif, kemudian dilakukan pengolahan dan analisis data. Metode analisis Hayami adalah metode yang umum digunakan untuk menganalisis nilai tambah pada subsistem pengolahan.

Hasil dari nilai tambah kacang sangrai UD. Merpati dapat dilihat pada tabel berikut.

\begin{tabular}{|c|c|c|}
\hline No. & & \\
\hline & $\begin{array}{l}\text { Keluaran (Output), Masukan (Input), dan } \\
\text { Harga }\end{array}$ & \\
\hline 1. & Output yang dihasilkan (kg/ proses produksi) & 300 \\
\hline 2. & $\begin{array}{l}\text { Bahan baku yang digunakan (kg/proses } \\
\text { produksi) }\end{array}$ & 500 \\
\hline 3. & Tenaga kerja (HOK/ proses produksi) & 7,45 \\
\hline 4. & Faktor konversi (kg output/kg bahan baku) & 0,6 \\
\hline 5. & Koefisien tenaga kerja (HOK/kg bahan baku) & 1,49 \\
\hline 6. & Harga output $(\mathrm{Rp} / \mathrm{kg})$ & 45.000 \\
\hline \multirow[t]{2}{*}{7.} & $\begin{array}{l}\text { Upah rata-rata tenaga kerja ( } \mathrm{Rp} / \mathrm{kg} \text { proses } \\
\text { produksi) }\end{array}$ & 1.980 \\
\hline & Pendapatan dan Keuntungan & \\
\hline 8. & Harga bahan baku (Rp/kg) & 4.000 \\
\hline 9. & Sumbangan input lain (Rp/kg output) & 800 \\
\hline 10. & Nilai output $(\mathrm{Rp} / \mathrm{kg})$ & 27.000 \\
\hline \multirow[t]{2}{*}{11.} & Nilai tambah (Rp/kg) & 22.200 \\
\hline & Rasio nilai tambah (\%) & 82,22 \\
\hline \multirow[t]{2}{*}{12.} & Imbalan tenaga kerja ( $\mathrm{Rp} / \mathrm{kg})$ & 2.950 \\
\hline & Bagian tenaga kerja $(\%)$ & 13,28 \\
\hline \multirow[t]{2}{*}{13.} & Keuntungan $(\mathrm{Rp} / \mathrm{kg})$ & 19.250 \\
\hline & Tingkat keuntungan (\%) & 71,29 \\
\hline \multirow[t]{4}{*}{14.} & Marjin (Rp./kg) & 23.000 \\
\hline & a. Pendapatan tenaga kerja $(\%)$ & 12,82 \\
\hline & b. Sumbangan input lain (\%) & 3,47 \\
\hline & c. Keuntungan $(\%)$ & 83,69 \\
\hline
\end{tabular}

Produksi kacang sangrai membutuhan bahan baku kacang mentah 500kg yang akan menghasilkan $300 \mathrm{~kg}$ kacang sangrai. Berdasarkan perhitungan diperoleh hasil bahwa nilai output kacang sangrai adalah $\mathrm{Rp}$. $45.000 / \mathrm{kg}$. berdasarkan nilai tersebut apabila nilai output dikurangi dengan biaya bahan baku dan input lain, nilai tambah yang dihasilkan dari pengelolahan kacang sangrai yaitu Rp. $22.200 / \mathrm{kg}$. 
Pendapatan yang diterima oleh tenaga kerja untuk memproduksi $1 \mathrm{~kg}$ kacang sangrai adalah Rp. 1.980,00 atau 13,28\% dari pendapatan yang diterima perusahaan. Selain itu keuntungan yang diperoleh perusahaan akibat adanya nilai tambah dalam pengelolahan kacang sangrai adalah Rp. 27.000 atau 71,29\%, apabila dibandingkan antara produk kacang sangrai dengan penjualan bahan baku mentah dapat diketahui bahwa produk kacang sangrai memiliki nilai yang lebih tinggi dari bahan baku mentah.

Besarnya margin yang diperoleh $12,82 \%$ menyumbang pendapatan untuk tenaga kerja, untuk sumbangan input lain $3,47 \%$ menjadi keuntungan perusahaan. Besarnya presentase keuntungan dari margin akibat pengolahan yang lebih dari $80 \%$ mengindikasikan bahwa produk kacang sangrai lebih menguntungkan dari pada menjual kacang tanah mentah.

Keuntungan pengusaha adalah presentase keuntungan terhadap marjin. Keuntungan sebesar Rp. $19.250 / \mathrm{kg}$ dibagi dengan marjin sebesar Rp. 23.000/kg dan dikalikan dengan $100 \%$, maka keuntungan pengusaha kacang sangrai UD. Merpati sebesar $83,69 \%$.

Nilai $83,69 \%$ adalah presentase keuntungan yang sangat besar untuk pelaku industri kacang sangrai UD. Merpati dilihat dari aspek pemasaran kacang sangrai dan banyaknya permintaan pasar, semakin banyak permintaan kacang sangrai tentu sangat berpengaruh terhadap keuntungan perusahaan UD. Merpati.

Kriteria nilai tambah (NT) adalah:

1) Jika NT > 0, berarti usaha pengelolahan kacang sangrai memberikan nilai tambah (positif).

2) Jika NT $<0$, berarti usaha pengelolahan kacang sangrai tidak memberikan nilai tambah (negatif).

Kriteria nilai tambah pada penelitian ini menunjukan hasil yang diperoleh lebih besar $>0$, berarti usaha pengelolahan kacang sangrai pada UD. Merpati di Desa Tombasian Atas Kecamatan Kawangkoan Barat Kabupaten Minahasa ini memberikan nilai tambah positif dengan presentase nilai sebesar $82,22 \%$. Nilai $82,22 \%$ merupakan nilai tambah yang dihasilkan oleh UD. Merpati ketika usaha tersebut menghasilkan $1 \mathrm{~kg}$ output maka akan menghasilkan nilai tambah sebanyak Rp.22.200. Nilai tambah 82,22\% adalah presentase nilai tambah yang sangat menguntungkan perusahaan karena dipengaruhi oleh kualitas dari industri kacang sangrai UD. Merpati itu sendiri juga dipengaruhi oleh harga bahan baku (input) yang masih tergolong murah dibandingkan ketika telah melewati pengelolahan (output) yang harganya sangat tinggi juga dipengaruhi dengan biaya sumbangan input lain yang tidak terlalu banyak karena semua alat untuk memproduksi kacang sangrai masih menggunakan alat-alat yang sangat tradisional.

\section{KESIMPULAN DAN SARAN}

\section{Kesimpulan}

Pengolahan kacang tanah mentah menjadi kacang sangrai pada UD. Merpati mengalami perubahan nilai yang lebih tinggi dibandingkan dengan belum diolah. Harga Output sebesar Rp. 45.000 menghasilkan keuntungan pada pengusaha sebesar Rp. $19.250 / \mathrm{kg}$ atau sebesar $71,29 \%$. Nilai tambah yang diperoleh pada usaha kacang sangrai UD. Merpati sebesar Rp. 22.200/kg dengan Rasio nilai tambah sebesar $82,22 \%$ memberikan nilai tambah yang positif.

\section{Saran}

UD. Merpati di Desa Tombasian Atas Kecamatan Kawangkoan Barat Kabupaten Minahasa diharapkan untuk memperluas kerja sama dengan pihak lain untuk meningkatkan produksi dan perluasan pasar. Perlu adanya variasi dalam olahan kacang tanah untuk melihat keuntungan produk dari kacang tanah. Dalam penelitian ini yang di analisis hanya kacang sangrai, Masih ada produk yang dapat diolah dari kacang tanah dan diharapkan juga untuk lebih mengembangkan sarana tempat produksi. 


\section{DAFTAR PUSTAKA}

Saragih, B. 2004. Paradigma Baru Pembangunan Ekonomi Berbasis Pertanian, Kumpulan Pemikiran. PT Surveyor Indonesia dan Pusat Studi Pembangunan LP-IPB. Jakarta.

Sjarkowi dan Sufri 2004. Definisi dan PengertianAgribisnis.

Hhtp://wordpress.com. tanggal 5 oktober 2019, 22.10.
Suryana, A. 2004. Arah Strategi dan Program Pembangunan Pertanian 20052009. Badan Litbang Pertanian. Departemen Pertanian.

Tambunan, T H. 2003. "Perkembangan Sektor Pertanian di Indonesia. Ghalia Indonesia, Jakarta. 